\title{
Y-Chromosomal Profile and Mitochondrial DNA of the Chevalier Bayard (1476?-1524)
}

\author{
Gérard Lucotte*, Alexandra Bouin Wilkinson \\ Institute of Molecular Anthropology, Paris, France \\ Email: *lucotte@hotmail.com
}

How to cite this paper: Lucotte, G. and Wilkinson, A.B. (2017) Y-Chromosomal Profile and Mitochondrial DNA of the Chevalier Bayard (1476?-1524). Open Journal of Genetics, 7, 50-61. https://doi.org/10.4236/ojgen.2017.71005

Received: February 23, 2017

Accepted: March 27, 2017

Published: March 30, 2017

Copyright (๑) 2017 by authors and Scientific Research Publishing Inc. This work is licensed under the Creative Commons Attribution International License (CC BY 4.0).

http://creativecommons.org/licenses/by/4.0/ (c) (i) Open Access

\begin{abstract}
Objective: We report the results of Y-chromosomal profile and mtDNA (mitochondrial DNA) of the Chevalier Bayard (1476?-1524). Methods: His genomic DNA was extracted from a tooth of his mandible. His Y-STRs profile was obtained using the AmFirst identifier PCR amplification kit. The mtDNA genomic sequence intervals for $H V R 1$ and $H V R 2$ were amplified by PCR, with specific primers. Results: We obtained the complete STR (Short Tandem Repeats) profile, based on fourteen STRs (DYS19, DYS385.a, DYS389.I and .b, DYS390, DYS391, DYS392, DYS393, DYS438, DYS439, DYS448, DYS456 and DYS458 and Y-GATA-H4). The deduced Y-STRs profile corresponds to the sub-clade S21 of the major European haplogroup R1b-M269 (the "Germanic" haplotype). There are six mutations (16093C, 16211T and 16519C in the $H V R 1$ sequence, 263G, 309.1C and 315.1C in the $H V R 2$ sequence) in the mtDNA of Bayard. The $263 \mathrm{G}$ mutation determines the $\mathrm{H}$ mtDNA haplogroup and the 16211T suggests the $\mathrm{H} 5$ sub-clade of the $\mathrm{H}$ haplogroup (a sub-clade found at $>8 \%$ frequency in France, at the periphery of the Alpine arch region). This sub-clade H5 (subsequently assimilated to the H10e haplotype) is that (with a perfect match) of a modern living male related (to 32 generations) to the Bayard maternal ascendance. The Bayard mtDNA haplotype was found once only in a database of 100 South-German mtDNA control sequences. Conclusions: The resulting R1b-M269 Y haplogroup established confirms the Germanic origin of the Bayard ancestors, suggested by genealogic studies concerning his paternal ascendance. The result concerning the mtDNA H10e haplotype found in the modern living male related to Bayard by matrilinear ascendance establishes that the DNA tooth is well of him, with a $99 \%$ of chance.
\end{abstract}

\section{Keywords}

The Chevalier Bayard, Tooth, Genomic DNA, Y-STRs Profile, mtDNA Mutations 


\section{Introduction}

The Chevalier Bayard (1476?-1524)—named Pierre (III) du Terrail—is well known in French history as "le chevalier sans peur et sans reproche". He is unanimously considered as the last true knight in shining armor, the last flower of the late Middle Ages, and the epitome of chivalry before the modern world took over [1].

As a soldier, Bayard was one of the most skilful commanders of his time. He served under three successive French kings: Charles VIII (with whom he participated to the conquest of the kingdom of Naples), Louis XII (with whom he acted to the conquest of Genoa) and François Ier. On the accession of François Ier in 1515, Bayard was made lieutenant-general (governor) of Dauphiné (a French region at this time); after the victory of Marignan, to which his valour largely contributed, he had the honour of being conferred knighthood from his youthful sovereign.

When the war broke out again between François Ier and Charles Quint (the Holy Roman Emperor), Bayard held Mézières against an army of 3500 men, and after six weeks compelled the imperial generals to raise the siege. This stubborn resistance saved central France from invasion. The parliament thanked Bayard as the saviour of his country and the king made him (in 1521) a knight of the order of Saint Michel.

In 1524, Bayard was sent to Italy with the Admiral Bonnivet, who had been defeated at Robecco and wounded in a combat. During the retreat of the French army Bayard repulsed the foremost pursuers, but in guarding the rear at the passage of the Sesia, was mortally wounded at Rovasenda (April 30, 1524) by an arquebuse ball which pierced his armor.

We do not know exactly when Bayard was born (between 1473 and 1476) but he was very probably born at Château Bayard (near Pontcharra, Isère), in Dauphiné.

Bayard was the second son (the third-born child of a kinship of eight children) of Aymon du Terrail (1458-1490), the second Lord de Bayard, and Hélène Alleman de Laval (born before 1436-died after 1504); we ignore the exact date of their marriage.

Bayard's cranium is at present kept in the Dauphiné Museum of Grenoble. We have reconstituted the whole Bayard cranium (Lucotte, unpublished) from his upper, lateral and posterior parts, his mandible and most of his osseous facial part. Detailed examination of the reconstituted cranium establishes that it is the skull of a Caucasian male, aged from 45 to 50 years; some observed particularities of the mandible (brachygnathy, elevated corpus, squared and non-protruding chin) correspond to those depicted on the portraits of Bayard.

A molar tooth was extracted from this mandible. Genomic DNA obtained from this tooth permits us to study the Y-chromosomal profile and the mtDNA (mitochondrial DNA) of Bayard, in a similar way to that recently explored [2] for King Richard III of England. 


\section{The Sample}

We extracted a tooth from the mandible articulated to the cranium. This incomplete cranium, presumed as the Bayard's skull, is stored in the Dauphiné $\mathrm{Mu}$ seum (Grenoble). This tooth (Figure 1) is the first molar located at the left side of the mandible (the tooth number 36 according to the Nomenclature Dentaire Internationale). The second root basis of that tooth was saved, and the interior of the canal of the crown was abrased with a dentist drill. The recuperated powder was sterilized, and then used for DNA extraction.

\section{Methods}

The dentine powder was washed with $15 \% \mathrm{HCl}$, rinsed with $\mathrm{UV}$-treated $\mathrm{ddd}_{2} \mathrm{O}$, and dried under an UV lamp for $15 \mathrm{~min}$.

The sterilized powder was introduced in $15 \mathrm{ml}$ tubes (Costar), and DNA was extracted according to a modified silica-based protocol [3]. Briefly, $2 \mathrm{ml}$ of an undiluted commercial guanidine thiocyanate solution $\left(\mathrm{DNAzol}^{\circledR}\right)$ was added to the tube and incubated at room temperature for 3 days; after that, the supernatant was passed through a silica column (QIAquick ${ }^{\circledast}$, Qiagen).

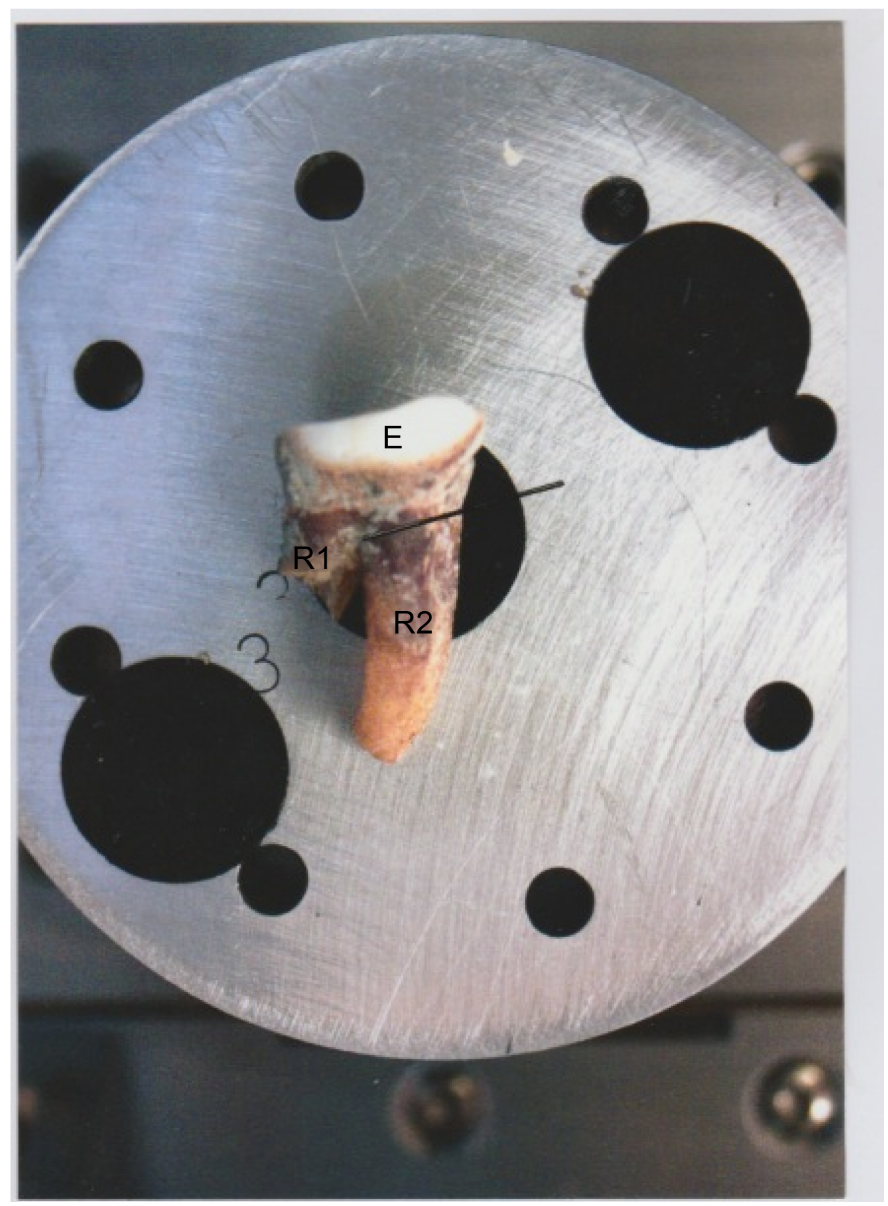

Figure 1. The tooth extracted from the mandible (lingual view). E: enamel, R1: the first (broken) tooth' root; R2: the second (sawed along the line) tooth root. 
All staff involved in the sampling wore protective clothing, sterile gloves and facemasks, to prevent exogenous contamination. DNA extraction and purifycation were performed according to our previously published protocol [4], in a dedicated laboratory.

We amplified from the genomic DNA extracted $14 \mathrm{Y}$-chromosomal short tandem repeats (Y-STRs) by using the AmFirst Identifier PCR amplification kit (Amp FIRSTLY filer ${ }^{\mathrm{TM}}$, Applied Biosystems), according to the instructions given by the Company; this amplification kit is specially adapted to the study of ancient DNA (a-DNA). The fifteen STRs studied are the followings: DYS19 (= DYS394), DYS385.a, DYS389.I and .b (DYS389.b = DYS389.II minus DYS389.I), DYS390 (=DYS708), DYS391, DYS392, DYS393 (=DYS395), DYS438, DYS439 (=Y-GATA-A4), DYS448, DYS456, DYS458, and DYS635 (=Y-GATA-C4); YGATA-H4 was detected in an independent PCR (Polymerase Chain) reaction. To detect the long STR alleles, we proceeded to two successive essays, with various degrees of stringency.

We predict, starting from the allele values, the corresponding $\mathrm{Y}$ haplogroup using the Whit Atey's Haplogroup Predictor [5].

From the genomic DNA extracted, we studied also the mtDNA. The mtDNA genomic sequence intervals for $H V R 1$ and $H V R 2$ (Hypervariable regions 1 and 2) were amplified by PCR with primers F15971 and R16610 and with primers L15 and H484, respectively. For each PCR, the DNA extract from the tooth root specimen was amplified by PCR in a $12.5 \mu$ reaction mixture: $2 \mathrm{mM} \mathrm{MgCl} 2,50$ $\mathrm{mM} \mathrm{KCl}, 10 \mathrm{mM}$ Tris/HCl $\mathrm{pH}=9,0.1 \%$ Triton X-100, $0.2 \mathrm{mM}$ each dNTP, 0.1 $\mu \mathrm{M}$ each primer, and $2.5 \mathrm{U}$ of DNA polymerase (Ampli Taq Gold; Applied Biosystems). The amplification was carried out with an initial denaturation step at $95^{\circ} \mathrm{C}$ for $6 \mathrm{~min}$., followed by 35 cycles at $95^{\circ} \mathrm{C}$ for $1 \mathrm{~min}$., $55^{\circ} \mathrm{C}$ for $1 \mathrm{~min}$., and $72^{\circ} \mathrm{C}$ for $1 \mathrm{~min}$.

PCR products were purified from agarose gel (QIA-Quick PCR purification kit; Qiagen). Both strands of all the amplified mtDNA fragments eluted from agarose gel slides were directy sequenced (Big Dye Terminator Cycle Sequencing kit; Applied Biosystems) and separated (ABI PRISM 3130 Genetic Analyzer; Applied Biosystem).

The sequences obtained were aligned against the Revised Cambridge Reference Sequence [6], to identify the presence of polymorphic sites. Seqscape software (Applied Biosystems) and Clustal analysis were used for pairwise alignment.

The laboratory performed DNA typing under strict precautions, following previously published criteria for ancient DNA authentication [7].

\section{Results}

A quantity of about $100 \mathrm{ng}$ of a total genomic DNA was obtained from the dental powder.

Preliminary experiments on the genomic DNA extracted established that it contains sequences of the amelogenin human gene, which show two peaks cor- 
responding to the two $\mathrm{X}$ and $\mathrm{Y}$ chromosomes. Consequently, the individual under study is truly a $\mathrm{XY}$ male.

Table 1 gives the allelic Y-STRs profile obtained. All these allele values were confirmed in a second PCR essay; we were not able to obtain the allele value corresponding to DYS635 (probably the longest).

The predicted Y haplogroup using the Haplogroup Predictor is I-M223.

We obtained DNA sequences (from 16,025 to 16,555 and from 67 to 369, respectively) of the $H V R 1(16,02416,569)$ and $H V R 2$ (1-576) segments of the mtDNA. Three mutations $(16093 \mathrm{C}, 16221 \mathrm{~T}$ and 16519C) are present in the HVR1 sequence, and three also (263G, 309.1C and 315.1C) in the HVR2 sequence. The same results were obtained in a replication study.

\section{Discussion}

In the present study we obtain, with genomic DNA extracted from one of his tooth, the Y-STRs profile (coming from his father) and the mtDNA sequence (coming from his mother) of Bayard.

The predicted Y-haplogroup I-M223 is equivalent to I2a2a, previously known as I2b1 of haplogroup I [8]. In fact one of us (G.L.) established that this haplogroup corresponds to the sub-clade S21/U106 of the major haplogroup R1bM269 [9]. In current European populations, this sub-clade shows a peak of S21 frequencies centred on Germany and surrounding areas (Figure 2); because of these particularities, it was named the "Germanic" Y-haplotype.

Table 2 summarizes what we know about the real paternal Bayard ancestry [10]. Bayard's father, Aymon du Terrail, was the second Lord de Bayard. His father, Pierre said "le Jeune" (1421-1460) was the first Lord de Bayard; his

Table 1. Y-chromosomal STR data analysis.

\begin{tabular}{ccc}
\hline Numbers & Y-STRs & Allele values \\
\hline $\mathbf{1}$ & DYS19 & 16 \\
$\mathbf{2}$ & DYS385.a & 14 \\
$\mathbf{3}$ & DYS389.I & 14 \\
$\mathbf{4}$ & DYS389.b & 18 \\
$\mathbf{5}$ & DYS390 & 24 \\
$\mathbf{6}$ & DYS391 & 10 \\
$\mathbf{7}$ & DYS392 & 12 \\
$\mathbf{8}$ & DYS393 & 14 \\
$\mathbf{9}$ & DYS438 & 10 \\
10 & DYS439 & 12 \\
11 & DYS448 & 20 \\
12 & DYS456 & 15 \\
13 & DYS458 & 16 \\
14 & DYS635 & $?$ \\
15 & Y-GATA-H4 & 11 \\
\hline
\end{tabular}


Table 2. Bayard's paternal ancestry.

\begin{tabular}{|c|c|c|c|c|}
\hline Generations & $\begin{array}{l}\text { Bayard paternal } \\
\text { ancestry }\end{array}$ & Names & $\begin{array}{l}\text { Birth- and } \\
\text { death rates }\end{array}$ & Titles \\
\hline 0 & Chevalier Bayard & $\begin{array}{l}\text { Pierre (III) du } \\
\text { Terrail }\end{array}$ & $1476 ?-1524$ & $\begin{array}{l}\text { third Lord de } \\
\text { Bayard }\end{array}$ \\
\hline 1 & Bayard's father & $\begin{array}{c}\text { Aymon (or } \\
\text { Amon) du Terrail }\end{array}$ & $1458-1490$ & $\begin{array}{l}\text { second Lord } \\
\text { de Bayard }\end{array}$ \\
\hline 2 & $\begin{array}{c}\text { Bayard's } \\
\text { grand-father }\end{array}$ & $\begin{array}{l}\text { Pierre II (junior) } \\
\text { du Terrail }\end{array}$ & $1421-1460$ & $\begin{array}{c}\text { first Lord de } \\
\text { Bayard }\end{array}$ \\
\hline 3 & Bayard's aïeul & $\begin{array}{l}\text { Pierre I (senior) } \\
\text { Terrail }\end{array}$ & $1387-1433 / 34$ & \\
\hline 4 & Bayard's bisaïeul & Pierre Terrail & ?-1387 & \\
\hline
\end{tabular}

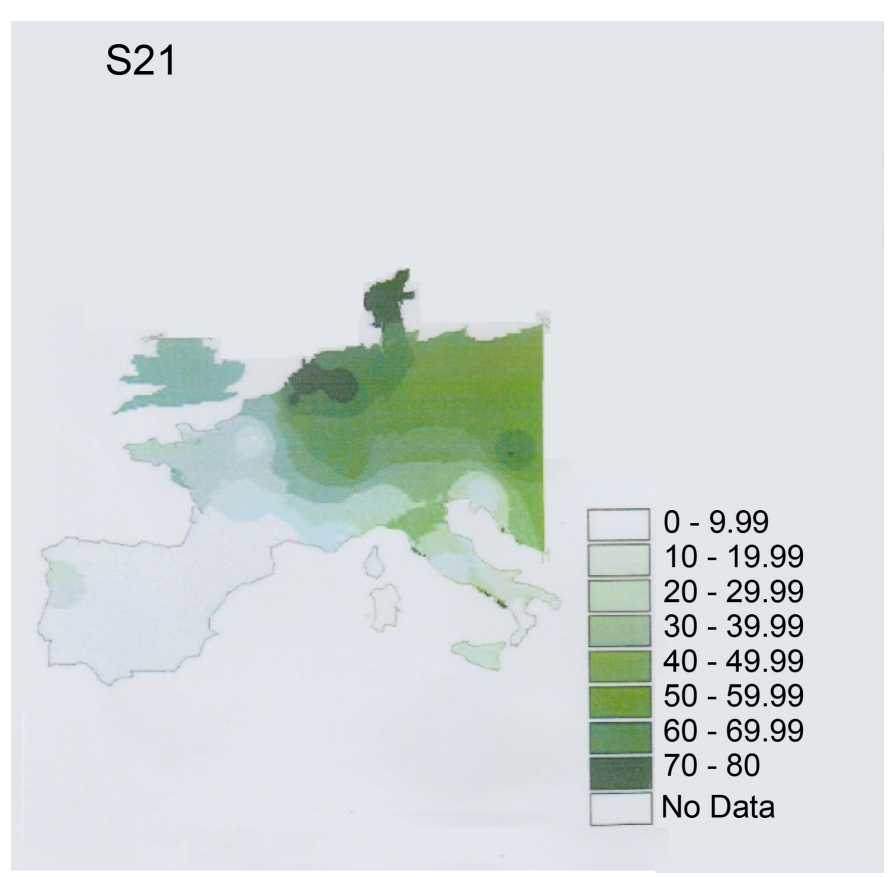

Figure 2. Isofrequency map of R-S21 in West-Europe (from Lucotte, 2015). Isofrequency lines indicate the artificial limits (of the areas with various nuances of green) between decreasing S21 values from the peak.

grand-father, Pierre said "le Vieux", was born in 1387 and died in 1433/34. We do not know the birth date of the ancestor Pierre Terrail, but he probably died in 1387. Nothing is known with certainty concerning Bayard's remote paternal ancestors.

Some past biographers spread various legendary accounts about Bayard's paternal ancestry [11]. But it is generally admitted that the House of de Terrail ("Terra alii" means stranger, in latin language) is very ancient in Dauphiné, and that they come from Germany ("at the time when the Emperors possessed the Dauphiné"). This explains why Bayard's Y-STRs profile corresponds to the Germanic Y-haplotype S21/U106.

The only-known Bayard descendant is an (illegitimate) daughter: Jeanne (1501- 
1580), who married in 1525 (one year after Bayard's death) to François II de Bocsozel (1483-1532); they have four sons: Pierre, Jehan, Piraud and Soffrey, but the break in the Bayard paternal transmission line (with Jeanne) do not permit us to compare their Y-STRs profiles (and those of their further male descendants) to that of Bayard.

Concerning now Bayard's mtDNA haplogroup, the $H V R 2$ sequence mutation $263 \mathrm{G}$ defines the mtDNA haplogroup $\mathrm{H}$; it is the most commonly found mtDNA haplogroup in Europe [12]. The HVR1 sequence mutation 16221T indicates (because of the absences of both $456 \mathrm{~T}$ and $16304 \mathrm{C}$ mutations) the $\mathrm{H} 5$ sub-clade of $\mathbf{H}$ [13].

The Eupedia map [14] of sub-clade $\mathrm{H} 5$ shows a remarkable concentration (that can attain $>8 \%$ ) of $\mathrm{H} 5$ frequencies (in West-Europe) at the near-periphery of the Alpine arch (in Slovenia, Austria, Switzerland and in the south-eastern part of France).

Bayard inherited his mtDNA haplotype from his mother Hélène Alleman de Laval. Now the Dauphiné region-from which Hélène came from-is located at the Western part of the Alpine arch periphery (an area with the maximal concentration of $\mathbf{H 5}$ frequencies). But, as for other European nobility [2], the female mobility of Hélène's family tends to be higher than the general population.

J. C. Parisot de Bayard, who funded this study, was able to identify a modern descendant of Bayard's family (Figure 3). This subject (named P. R.) is a living male individual born near the town of Annecy (in Savoy), 32 generations removed from Bayard (from his mother Hélène Alleman du Terrail) on the female line.

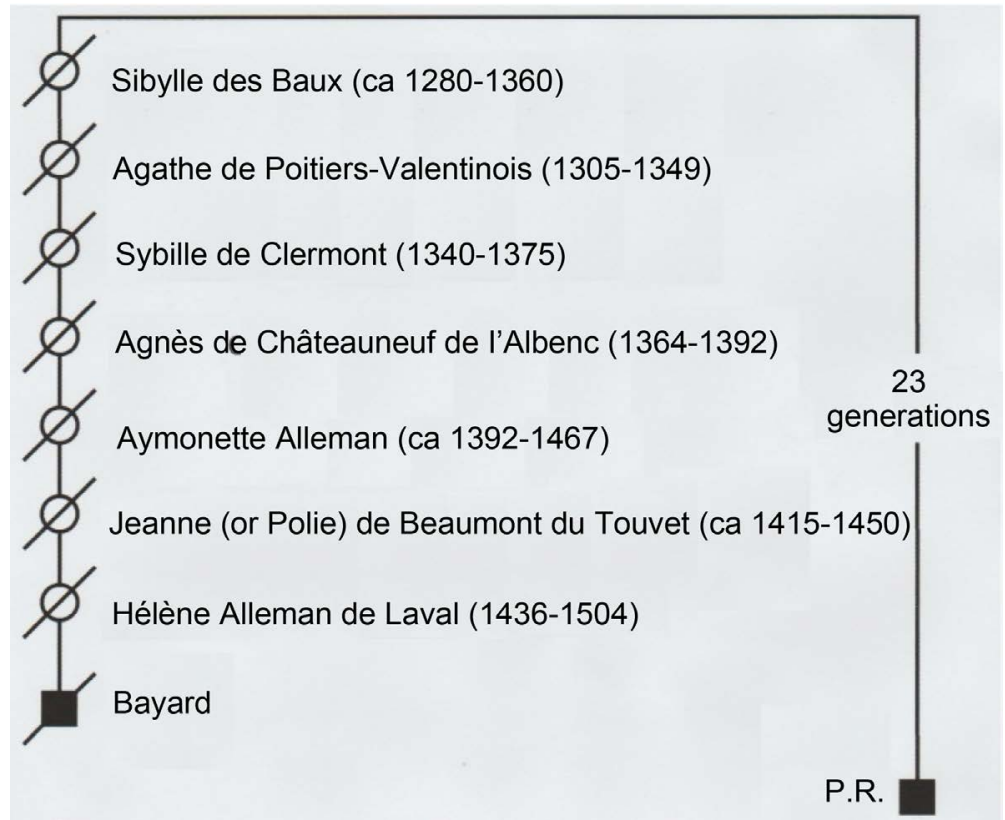

Figure 3. Genealogical links between Bayard and a modern-day relative (P. R.) who participated in this study. Genealogical information links P. R. (who descended from Bayard's mother) and Bayard through a female-only line (ca: circa). 
The mtDNA analysis (repeated twice) of P.R. shows a perfect match (he had the three HVR 1 mutations $16093 \mathrm{C}, 16221 \mathrm{~T}$ and $16519 \mathrm{C}$, and the three other HVR2 mutations 263G, 309.1C and 315.1C) between his mtDNA haplotype and that of Bayard; this is consistent with this subject being a matrilineal relative-in a similar form that it was found in [2]-at the genealogical time depth considered.

In contrast to false paternity, false-maternity is much less likely [2]; but historical records of female-line lineages are usually more difficult to track over multiple generations, due to the change of women's surnames after marriage. In the case reported here, the family tree concerns noble families (often better recorded) tracing down from Bayard to the beginning of the $13^{\text {th }}$ century.

Because of the maximal value of $>8 \%$ observed frequency of the sub-clade H5 in the geographic region considered, we considered at first that there is less than about $10 \%$ of probability that the mtDNA match between P.R. and Bayard could have occurred by chance. But that is certainly an overestimate, because Bayard's mtDNA haplotype (Table 3 ) is only one of those constituting haplogroup H5 considered as a whole. To note that the attribution adopted here to consider Bayard's mtDNA haplogroup as being of the sub-clade $\mathrm{H}$ (usually determined by the two supplementary mutations $16304 \mathrm{C}$ and $456 \mathrm{~T}$ ) is entirely due to the presence in it of the $16221 \mathrm{~T}$ mutation; this mutation is generally considered, together with the $16085 \mathrm{~T}$ and 16106A mutations, as a typical "Alpine mutation" [15].

Next we investigated more precisely the probability that Bayard's mtDNA haplogroup had occurred by chance, by tempting to find it in three databases of complete mtDNA control sequences concerning subjects originating from geographic regions located in the North periphery of the Alpine arch. These three databases are: 1/a first database [16] concerning 104 Slovenians and 144 Bosnians; 2/a second database [17] concerning 273 unrelated West-Eurasians from Austria; 3/a third database [18] concerning one hundred of samples that were collected from native German speakers in the middle of Southern Germany (in the region of Ulm city, that is located between Lake Constance and the Swabian Alps).

The only perfect match we found is for the UL1A8 subject of South-Germany (Table 4) of the third database; he is nomenclatured under the mtDNA haplogroup $\mathrm{H}^{\star}$ (the paragroup). So, for this geographic region , we found Bayard's

Table 3. Bayard's mtDNA haplotype.

\begin{tabular}{|c|c|c|}
\hline HVR sequences & Mutations & Comments \\
\hline \multirow[t]{3}{*}{1} & $16093 \mathrm{C}$ & $\begin{array}{l}\text { this variant appeared in about } 5 \% \text { of most } \\
\text { haplogroups, but most commonly in } \mathbf{K}\end{array}$ \\
\hline & $16221 \mathrm{~T}$ & indicates the $\mathrm{H} 5$ sub-clade of $\mathrm{H}$ \\
\hline & 16519C & $\begin{array}{c}\text { corresponds to a hotspot; it appears in almost every } \\
\text { haplogoup, in over half of them }\end{array}$ \\
\hline \multirow[t]{3}{*}{2} & $263 \mathrm{G}$ & determinates the $\mathrm{H}$ haplogroup \\
\hline & $309.1 \mathrm{C}$ & is one of the most recurrent mutation \\
\hline & $315.1 \mathrm{C}$ & most members of $\mathrm{H}$ also have this mutation \\
\hline
\end{tabular}


Table 4. Results of the research to find the Bayard mtDNA haplotype in three databases of mtDNA control sequences.

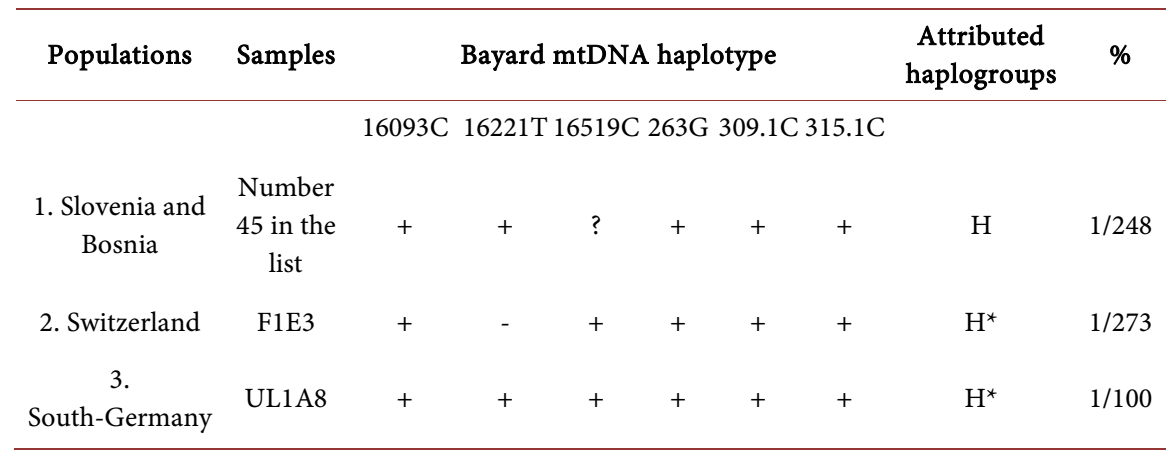

+indicates presence of the mutation; -: their absence; ?: uncertain.

mtDNA haplotype at a frequency of $1 / 100$.

The subject number 47 (a Slovenian) of the first database is of a mtDNA haplogroup very similar to that of Bayard's (but he had $150 \mathrm{~T}$ as a supplementary mutation in the HVR2 sequence); the reason why he had not $16519 \mathrm{C}$ is that the second primer of the PCR reaction used for $H V R 1$ sequence covers until 16400 only. The nearest mtDNA haplotype we found in the second database is that of the Swiss f1E3 subject (but he had 16271C as a supplementary mutation in the $H V R 1$ sequence); the fact that he had not $16221 \mathrm{~T}$ is possibly related to the event that this variant could be a phantom mutation [19], that is a systematic artefacts generated in the course of the sequencing process itself.

A synthetic study [20] concerned an analysis of $1350 \mathrm{mtDNA}$ haplotypes belonging to $\mathrm{H}$, originating from Central Europe: Austria $(\mathrm{H}$ samples $=973)$, Germany (=31), Hungary (=71), Macedonia (=100), Romania (=124), and from Dubaï (=51). The prevalence of sub-clades H1, H5, H6 and H10 (defined by the 16093C and 16221T mutations), H13, H14, H15, H16, H17 and H21 was consistent across Europe; the H10 sub-clade particularly concerns 44 samples (3.3\% of the total), but manifests hardly and genetic heterogeneity.

Today [21] the 16221T mutation defines the H10e type. Various sub-types of $\mathrm{H} 10 \mathrm{e}$ are characterized by some specific mutations (Table 5). We had the opportunity to examine 56 mitogenomes (complete mtDNA sequences) belonging to H10e for the presence of the Bayard mtDNA haplotype: three H10e1 sequences (among 9), four H10e1a (among 6), three H10e2 (among 4) and one H10e3a (among 2) contained it.

Among the thirty five mitogenomes examined, twelve of them (Table 6) are of the Bayard mtDNA haplogroup: three subjects from Denmark, three from UK, two from England, one from Wales, one from France (he is not P.R.) and two from USA (who revendicate remote Anglo-Saxon ancestries).

\section{Conclusion}

In conclusion, it is the first time that the DNA of the Chevalier Bayard is studied (for paternal and maternal ancestries). His Y-STRs profile shows that he belongs to the Germanic S21/U106 Y haplogroup sub-clade. His mtDNA haplogroup, 
Table 5. Characteristic mutations of the H10e haplogroup type and of four sub-types found in the collection of 56 mitogenomes bearing the Bayard mtDNA haplotype.

\begin{tabular}{ccc}
\hline Type & Mutations & Numbers found \\
\hline H1Oe & $16221 \mathrm{~T}$ & 35 \\
Sub-types & & 9 \\
H10e1 & $13830 \mathrm{C}$ & 6 \\
H10e1a & $16266 \mathrm{~T}$ & 4 \\
H10e2 & $14602 \mathrm{G}$ & 2 \\
H10e3a & $961 \mathrm{C}$ & \\
\hline
\end{tabular}

Table 6. Characterisations of the twelve H10e mitogenomes (on 35) of the Bayard mtDNA haplotype.

\begin{tabular}{cccc}
\hline Numbers (on 12) & Numbers (on 35) & GenBank ID & Geographic origins \\
\hline $\mathbf{1}$ & 7 & KF161474 & Denmark \\
$\mathbf{2}$ & 26 & JX153333 & Denmark \\
$\mathbf{3}$ & 29 & KF161060 & Denmark \\
$\mathbf{4}$ & 11 & JQ701809 & UK \\
$\mathbf{5}$ & 21 & JQ705324 & UK \\
$\mathbf{6}$ & 24 & JQ705702 & UK \\
7 & 14 & JQ703082 & England \\
$\mathbf{8}$ & 18 & JQ704209 & England \\
$\mathbf{9}$ & 17 & JQ704082 & Wales \\
10 & 5 & HQ662520 & France \\
11 & 3 & GU569076 & USA \\
12 & 4 & HM101252 & USA \\
\hline
\end{tabular}

found again in a living male individual removed from 32 generations on the female line of Bayard ancestry, is of the $\mathrm{H} 5$ sub-clade further precised as being the H10e type. The Bayard mtDNA haplotype is found at an approximate percentage of $1 / 100$ in the geographic region located at the periphery of the Alpine arch. We now move towards phenotypical DNA markers concerning his skin, eyes and hair pigmentation and his nose and chin forms, in order to compare them to the corresponding characters observable on Bayard's portraits.

\section{Acknowledgements}

We thank T. Tomasset (UST of Compiègne) for the photograph of the tooth; R. Rottenberg (Rosny-sous-Bois) for the obtaining of the dentine powder of the interior of the tooth; F. Dieterlen (Geneva, Switzerland) for his help to construct the Y-SNP S21 isofrequency map. P. R. (Annecy) accepted to participate anonymously to the study. The Prefect J. C. Parisot de Bayard (Peols) provided a detailed genealogy linking P.R. to Bayard (his remote ancestor). We acknowledge J. P. Jospin, Chief Curator at the Dauphiné Museum, who permitted to one of us (G. L.) to have access to the cranium. Thanks to Pr A. Torroni (Pavia Uni- 
versity, Italy) who informed us about the most recently progress concerning 56 mitogenomic sequences belonging to $\mathrm{H} 10 \mathrm{e}$.

\section{Funding}

The present work was realized with the financial help of J. C. Parisot de Bayard and of "les Amis de Bayard" Association.

\section{Conflict of Interest}

The authors declare no conflict of interest.

\section{References}

[1] Champier S. (1525) The Whole Life of the Brave Chevalier Bayard. Gilbert de Villiers Editor, Lyon.

[2] King, T.E., Gonzalez Fortes, G., Balareque, P., Thomas, M.G., Balding, D., Maisano Delser, P., et al. (2014) Identification of the Remains of King Richard III. Nature Communications, 5, Article No. 5631. https://doi.org/10.1038/ncomms6631

[3] Höss, M. and Pääbo, S. (1993) DNA Extraction from Pleistocene Bones by a Silica-Based Purification Method. Nucleic Acids Research, 21, 3913-3914. https://doi.org/10.1093/nar/21.16.3913

[4] Lucotte, G. (2010) A Rare Variant of the mtDNA HVS1 Sequence in the Hairs of Napoléon's Family. Investigative Genetics, 1, 7-10. https://doi.org/10.1186/2041-2223-1-7

[5] Athey, T.W. (2006) Haplogroup Prediction from Y-STR Values Using a Bayesian Allele Frequency Approach. Journal of Genetic Genealogy, 2, 34-39.

[6] Andrews, R.M., Kubacha, I., Chinnery, P.F., Lightowlers, R.N., Turnbull, D.M. and Howel, N. (1999) Reanalysis and Revision of the Cambridge reference Sequence for Human Mitochondrial DNA. Nature Genetics, 23, 147. https://doi.org/10.1038/13779

[7] Hofreiter, M., Serre, D., Poinar, H.N., Kuch, M. and Pääbo, S. (2001) Ancient DNA. Nature Reviews Genetics, 2, 353-359. https://doi.org/10.1038/35072071

[8] Athey, T.W. and Nordtvedt, K. (2005) Resolving the Placement of Haplogroup I-M223 in the Y-Chromosome Phylogenetic Tree. Journal of Genetic Genealogy, 1, 54-55.

[9] Lucotte, G. (2015) The Major Y-Chromosome Haplogroup R1b-M269 in WestEurope, Subdivided by the Three SNPs S21/U106, S145/L21 and S28/U152, Shows a Clear Pattern of Geographic Differentiation. Advances in Anthropology, 5, 22-30. https://doi.org/10.4236/aa.2015.51003

[10] Verdier, R. (2007) Des Terrail à Bayard, in "Cross Stories of the Chevalier Bayard". University Press of Grenoble Editor, 41-54.

[11] Parisot de Bayard, J.C. (2016) Genealogy of the Magnificent Chevalier Bayard. Christian Editor, Paris.

[12] Roostalu, U., Kutuev, I., Loogväli, E.L., Metspalu, E., Tambets, K. and Reidla, M. (2006) Origin and Expansion of Haplogroup H, the Dominant Human Mitochondrial DNA Lineage in West Eurasia: The Near Eastern and Caucasian Perspective. Molecular Biology and Evolution, 24, 436-448. https://doi.org/10.1093/molbev/msl173

[13] List of Mitochondrial DNA (mtDNA) Haplogroups and Subclades with Their De- 
fining Mutations. http://www.eupedia.com/europe/Haplogroup_H_mtDNA.shtml

[14] Eupedia: haplogroup H (mtDNA), see Eupedia map of mtDNA haplogroup H5.

[15] Malyarchuck, B.A. and Derenko, M.V. (1999) Molecular Instability of the Mitochondrial Haplogroup T Sequences at Nucleotide Positions 16292 and 16296. Annals of Human Genetics, 63, 489-497. https://doi.org/10.1046/j.1469-1809.1999.6360489.x

[16] Malyarchuk, B.A., Grzybowski, T., Dorenko, M.V., Czarny, J., Drobnic, K. and Miscicka-Sliwka, D. (2003) Mitochondrial DNA Variability in Bosnians and Slovenians. Annals of Human Genetics, 67, 412-425. https://doi.org/10.1046/j.1469-1809.2003.00042.x

[17] Bandstätter, A., Niederstätter, H., Pavlic, M., Grubwieser, P. and Parson, W. (2007) Generating Population Data for the EMPOP Database-An Overview of the mtDNA Sequencing and Data Evaluation Processes Considering 273 Austrian Control Region Sequences as Example. Forensic Science International, 166, 164-175. https://doi.org/10.1016/j.forsciint.2006.05.006

[18] Bandstätter, A., Klein, R., Duftner, N., Wiegand, P. and Parson, W. (2006) Application of a Quasi-Median Network Analysis for the Visualization of Character Conflicts to a Population Sample of Mitochondrial DNA Control Region Sequences from Southern Germany (Ulm). International Journal of Legal Medicine, 120, 310 314. https://doi.org/10.1007/s00414-006-0114-x

[19] Bandelt, H.J., Quintana-Murci, L., Salas, A. and Macaulay, V. (2002) The Fingerprint of Phantom Mutations in Mitochondrial DNA Data. American Journal of Human Genetics, 71, 1150-1160. https://doi.org/10.1086/344397

[20] Brandstäter, A., Zimmermann, B., Wagner, J., Göbel, T., Röck, A.W., Salas, A., et al. (2008) Timing and Deciphering Mitochondrial DNA Macro-Haplogroup R0 Variability in Central Europe and Middle East. BMC Evolutionary Biology, 8, 191. https://doi.org/10.1186/1471-2148-8-191

[21] Phylo Tree. Org-mtDNA Tree Build 17.18 Feb 2016: Subtree RO.

\section{Scientific Research Publishing}

\section{Submit or recommend next manuscript to SCIRP and we will provide best} service for you:

Accepting pre-submission inquiries through Email, Facebook, LinkedIn, Twitter, etc. A wide selection of journals (inclusive of 9 subjects, more than 200 journals)

Providing 24-hour high-quality service

User-friendly online submission system

Fair and swift peer-review system

Efficient typesetting and proofreading procedure

Display of the result of downloads and visits, as well as the number of cited articles

Maximum dissemination of your research work

Submit your manuscript at: http://papersubmission.scirp.org/

Or contact ojgen@scirp.org 